Primljen / Received: 11.3.2017. Ispravljen / Corrected: 23.2.2018.

Prihvaćen / Accepted: 4.3.2018. Dostupno online / Available online: 10.7.2018.

\title{
Parametric study of geocell reinforced pavement
}

Authors:

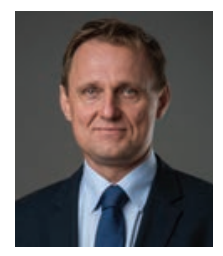

Samo Peter Medved, Bojan Žlender, Stanislav Lenart

Preliminary report

\section{Parametric study of geocell reinforced pavement}

Parametric study of geocell reinforced pavement is presented in this paper. The FEM analysis models include unreinforced pavement structures and geocell-reinforced pavements with various geocell positions, thicknesses and strengths. The model output includes the expected life of the pavement. Parametric study results are consistent with the results of analytical solutions, laboratory tests, and field-test experiments. The results reveal a significant improvement in capacity, reduction in asphalt-layer thickness, and an increase in life expectancy of the geocell-reinforced pavement structure.

Key words:

flexible pavement, geocell, geosynthetic, reinforced soil, numerical modelling

Prethodno priopćenje

Samo Peter Medved, Bojan Žlender, Stanislav Lenart

\section{Parametarska studija kolničke konstrukcije ojačane geoćelijama}

Assoc. Prof. Bojan Žlender, PhD. CE

University of Maribor

Faculty of Civil Engineering

bojan.zlender@um.si

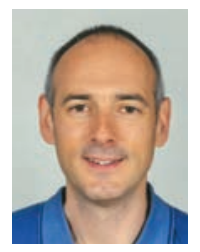

U radu je prikazano parametarsko ispitivanje kolničke konstrukcije ojačane geoćelijama. Analiza temeljena na metodi konačnih elemenata uključuje model neojačane kolničke konstrukcije te model kolničke konstrukcije ojačane geoćelijama, pri čemu se analiziraju razni položaji, debljine i čvrstoća geoćelija. U okviru modela određen je i očekivani vijek trajanja kolničke konstrukcije. Rezultati parametarskog proučavanja u skladu su s rezultatima analitičkih rješenja, laboratorijskih i terenskih ispitivanja. Dobiveni rezultati upućuju na bitno poboljšanje nosivosti, smanjenje debljine asfaltnih slojeva i povećanje trajnosti kolničke konstrukcije kada je ona ojačana geoćelijama.

Ključne riječi:

savitljivi kolnik, geoćelija, geosintetik, ojačano tlo, numeričko modeliranje

Vorherige Mitteilung

Samo Peter Medved, Bojan Žlender, Stanislav Lenart

\section{Parameteruntersuchung der durch Geozellen verstärkten Fahrbahnkonstruktion} stanislav.lenart@zag.si

In der Abhandlung wird die Parameteruntersuchung der die sich auf den Ergebnissen der FEM begründen. Die auf der FEM begründete Analyse umfasst das Modell der nicht verstärkten Fahrbahnkonstruktion sowie das Modell der durch Geozellen verstärkten Fahrbahnkonstruktion, wobei verschiedene Positionen, Stärken und Festigkeiten der Geozellen analysiert werden. Im Rahmen der Modelle wurde auch eine erwartete Nutzungsdauer der Fahrbahnkonstruktion festgelegt. Die Ergebnisse der Parameterstudie stimmen mit den Ergebnissen der analytischen Lösungen, der Labor- und Felduntersuchungen überein. Die erhaltenen Ergebnisse weisen auf eine wesentliche Verbesserung der Tragfähigkeit, die Verringerung der Stärke der Asphaltschichten sowie die Erhöhung der Haltbarkeit der Fahrbahnkonstruktion hin. 


\section{Introduction}

Pavement structures are an important element of any road. They represent at least $40 \%$ of the total investment costs of roads and about $70 \%$ of the maintenance management costs. According to the Road Statistics Yearbook, 2016 [1], the EU has over 4.8 million $\mathrm{km}$ of paved roads. To achieve an appropriate quality of roads, at least $6 \%$ of the length of the entire network must be built or restored each year. This involves considerable quantities of built-in material, high energy consumption, and significant costs. Therefore, finding alternative ways to design pavement structures is a permanent engineering challenge, and has been the subject of numerous studies.

This paper focuses on geocell reinforced flexible pavements. An investigation of the effects of geocell reinforcement on pavements was carried out. The basic purpose of the investigation was to find the capacity, durability and costoptimized solution for such a project, while attempts were simultaneously made to try to minimize consumption of materials and energy.

In recent years, several researchers, such as Cowland and Wong, Dash et al., and Yang et al. [2-5], have focused on studying geocell soil reinforcement and the improvement of soil bearing capacity of embankments in which geocells are used. They found that an appropriate geometry of geocells is effective for improving load capacity. Some other researchers, such as Bathurst and Karpurapu [6], Rajagopal et al. [7], Mengelt et al. [8], Wasseloo et al. [9], and Pokharel et al. [10], have studied the effect of geocells on deformed ground, and the impact on soil modulus under static and dynamic load. The results of their research have shown that the capacity of the base material can be improved by using geocells, which depends on the load, geocell type and type of load. Mengelt et al. [8] investigated the ways in which the use of geocells increases elastic modulus of pavement layers. The above-mentioned studies were specifically focused on testing single geocells structures. Rajagopal et al. [7] and Wasseloo, et al. [9] carried out research on the deformation characteristics of pavements reinforced with several geocell layers. They mostly used geocells $100 \mathrm{~mm}$ and $200 \mathrm{~mm}$ in thickness. The results show that the use of geocells reduces the occurrence of rutting in road surfaces. Al-Qadi and Hughes [11] studied the effect of non-woven geosynthetic geocells, with heights of $100 \mathrm{~mm}$. An analysis using the Falling Weight Deflectometer (FWD) showed that the elastic modulus increased by a factor of 2 over a three-year period in the pavements reinforced with geocells. Latha et al. [12] conducted a field study of geocells on unpaved roads, using geocells from various types of geosynthetics. Pokharel, et al. [10] examined the use of Neoloy polymer geocells as reinforcement on low traffic unpaved roads, constructed over a subgrade with a CBR lower than 3 . This study shows that the use of thinner and more rigid geocells can be even more effective.
A parametric study of geocell reinforced pavement using the Finite Element Method (FEM) is presented in this paper. The method is implemented by installing geocells in the base layer to prevent excessive horizontal deformation. This increases the overall capacity of the pavement. For this purpose, an extensive research work was conducted, involving analytical solutions, numerical analyses with parametric studies, experimental analyses with laboratory experimental tests, and a field-test experiment. The research was based on previous laboratory TLS tests [13] conducted using a new testing device, and referred to as the Traffic Load Simulator (TLS). This device was constructed at the Slovenian National Building and Civil Engineering Institute (ZAG). The aim of this experimental campaign was to perform laboratory tests on full-scale pavement structures subjected to traffic load. The mathematical model for the multi-layer system was derived from a geocell-reinforced pavement analysis. The model combines known empirical relationships with a representation of the physics and mechanics behind the flexible pavement behaviour. The mathematical model is a useful indicator for the effectiveness of pavement structure. The use of the model is presented via the TLS test results [14]. Experimental and theoretical analyses show significant improvement in capacity and reduction of deformation when geocells are used. By using geocells, the bearing capacity and the elastic area of the unbound bearing layer are increased, while permanent deformation to pavement structure is decreased. This method has been tested in the field on geocell reinforced pavement structures, which were compared to unreinforced pavements structures. The geocell efficiency was also confirmed by field experiments [14, 15]. Initial results show that geocells embedded in unbound bearing layers provide pavement structures with flexibility and sufficient capacity. The investigations will continue in the future, with the focus on the time-effect of geocell reinforced pavements.

This paper presents only the results of a parametric study conducted on an investigated pavement structure using the Finite Element Method (FEM). Other laboratory experiment and field test results are presented elsewhere [13-15].

\section{Concept of geocell reinforced pavement}

Pavement structures are reinforced by installing geocells in the base layer (Figure 1). This is intended to prevent excessive horizontal deflection of unbound supporting layers of the pavement structure and to simultaneously increase capacity of the entire pavement structure. As the use of geocells limits movements in the horizontal direction, it also enables additional horizontal confinement of the base layer.

The construction of geocell pavement structures is simple. Geocells are placed in a base layer and filled with gravel material. The material in the cells is first vibrated into 
place using a compactor plate. The dynamic and static compacting with a heavier compactor is then conducted at the pre-prepared base. Medved et al. [14] tested this type of installation technology. The field test in this area showed that the installation technology is fully effective and unproblematic.
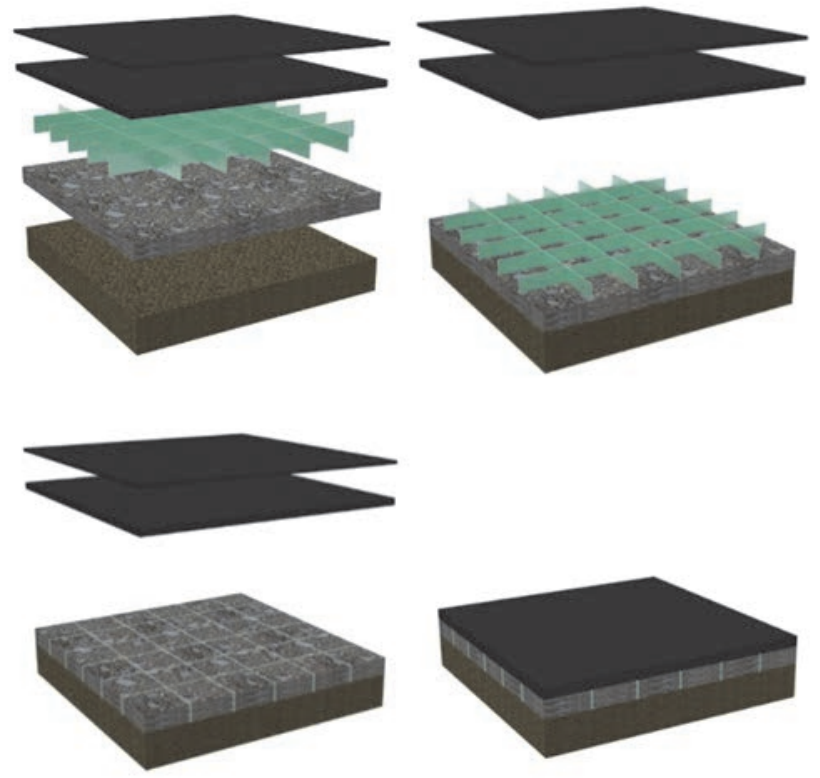

Figure 1. Geocell reinforced flexible pavement concept: layers (upper left), installation of geocells (upper right), geocells with compacted crushed stone material (bottom left) and final pavement structure (bottom right)

Mechanisms of the effect of reinforcing pavement structures with geocells have been explored in detail by several authors [16-18]. In principle, there are three main mechanisms by which geocells can have an increasing effect on the capacity of reinforced layers: the mechanism of lateral resistance (cell-effects), the mechanism of stress dispersion, and the membrane effect mechanism.

The mechanism of lateral resistance results from friction between the geosynthetic reinforcement and the soil. In this case, the shear stress is efficiently transmitted from the soil, by friction to the tension in the geosynthetic reinforcement. Figure 2 shows a cross-sectional view and the unitary pocket shear force.

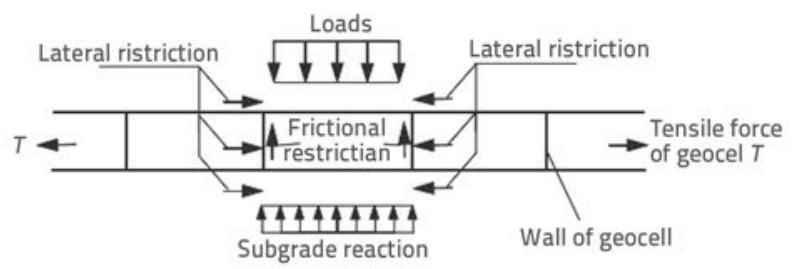

Figure 2. Mechanism of lateral resistance, Ling [17]
The confinement effect improvement is the sum of the unitary pocket shear forces under load, obtained by multiplying the number of cells under load by the unitary pocket shear force [18].

$\Delta F_{\tau}=4 \cdot \frac{h}{d} \cdot k_{0} \cdot p \cdot B \cdot L \cdot \tan \delta$

where: $\Delta F_{t}$ is the sum of unitary pocket shear forces under load (confinement effect improvement), h/d is the geocell aspect ratio, $\mathrm{k}_{0}$ is the lateral earth pressure at rest $\left(\mathrm{k}_{0}=1-\sin \phi^{\prime}\right), B$ and $L$ are the load width and load length, $\delta$ is the interface friction angle between the filling soil and the geocell wall, and p is the load at the top of the geocell mattress.

Figures 3 and 4 show the bearing capacity mechanism and the force vectors by using the membrane effect mechanism. The second improvement effect is the stress distribution mechanism [16]. The stress in the upper level of the geocells is reduced at the lower level from $p$ to $p^{\prime}$.

$p^{\prime}=\frac{\left(B+2 \cdot h_{C E L} \cdot \tan \alpha\right)}{B}$

where: $p$ is the stress on the upper level of the geocell, $p^{\prime}$ is the stress on the basis of the geocells, $B$ is the load width, $h_{C \mathrm{C}}$. is the thickness of the geocells, and $\alpha$ is the angle of stress distribution.

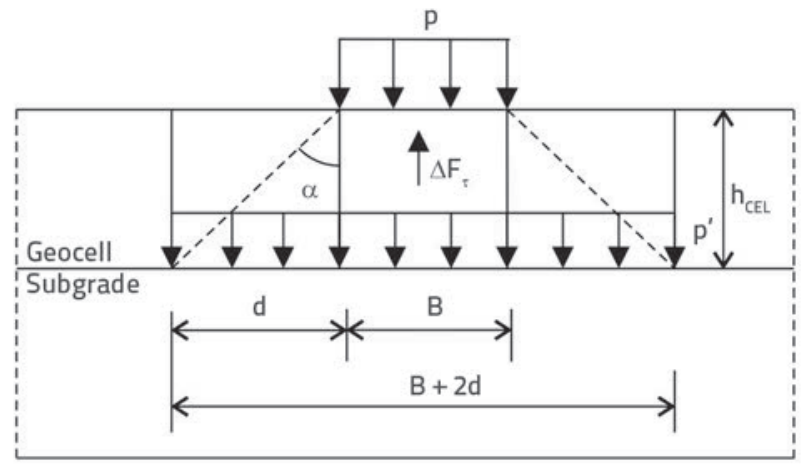

Figure 3. Stress distribution capacity increase mechanism

The third improvement effect is the membrane mechanism [17], which occurs when the reinforced soil has already developed a certain deformation. The increase in capacity is calculated from the tensile force in geocells, eq (3):

$\Delta p=\frac{2 \cdot T \cdot \sin \alpha}{B}$

The tension force is given by equation (4):

$T=E_{C E L} \cdot \varepsilon_{C E L} \cdot h_{C E L}$

where: $\Delta \mathrm{p}$ is the bearing capacity increment, $B$ is the width of the uniform load, $E_{C E L}$ is the tensile elasticity modulus of the geocell; $\varepsilon_{C E L}$ is the tensile strain of the geocell layer, $h_{C E L}$ is the thickness of the geocells and $\alpha$ is the horizontal angle of the tensional 
force $T$. Figure 4 shows the bearing capacity mechanism by membrane effect and the force vectors.

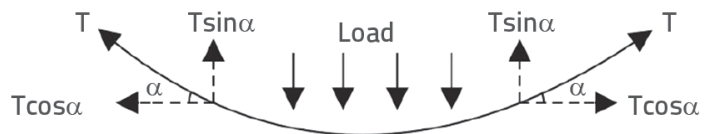

Figure 4. Membrane mechanism

\section{Material properties}

\subsection{Geocells}

Geocells are made up of vertically-oriented strip-form cells that can assume rectangular, square or hexagonal forms (Figure 5). Stone material is laid into the cells and compacted up to an optimum value. The cells are of an appropriate size: the spacing between the bands is greater than three times the maximum grain, and no smaller than the thickness of the layers (i.e. than the geocell layer thickness). Geocells range from 5 to $20 \mathrm{~cm}$ in thickness. Most previous researchers tested geocells varying from 10 to $20 \mathrm{~cm}$ in thickness. Geocells can assume two extreme positions in the base layer of the pavement structure: the extreme position in contact with ground, and the extreme position in contact with asphalt.

Geocells have been recognized as a suitable geosynthetic reinforcement of granular soils for supporting static and moving wheel loads on roadways. The analysis considers the stiffness of geocells with the elastic modulus $E_{C E L}$ ranging from $200 \mathrm{MPa}$ to $3000 \mathrm{MPa}$.

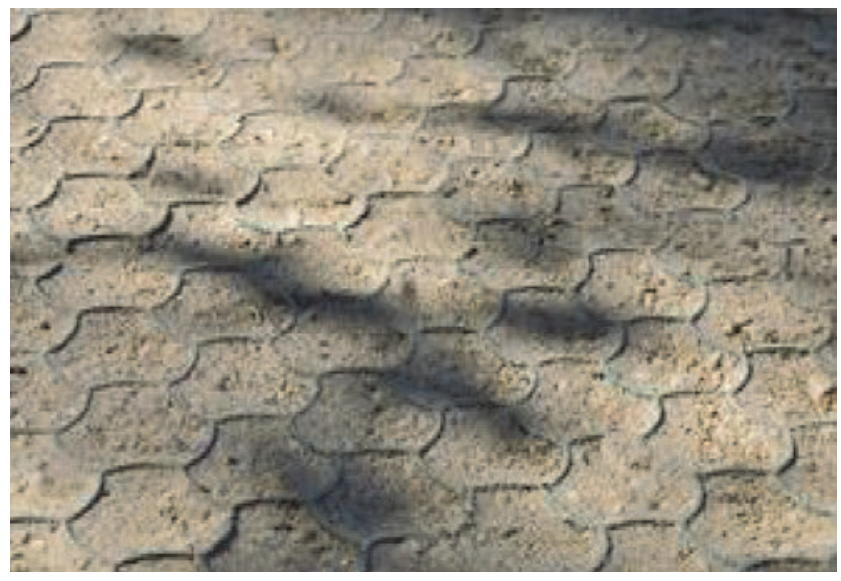

Figure 5. Geocells in pavement structure before asphalt laying

\subsection{Asphalt layers}

The asphalt layer was treated in the analysis as an elastic material with a modulus of elasticity of $E_{A C}$ and a Poisson ratio of $v_{A C}$ The fatigue of the asphalt due to repeated loads is given by the maximum number of cyclical repetitions of load, specified as a function of deformation.

\subsection{Base and sub-base layers}

The modulus of elasticity of base layer may be constant throughout the layer, or it can be expressed as a function of stress. In the analysis presented in this paper, the modulus of elasticity is expressed as a function of stress. Witczak and Uzan [19] modified the model by including the octahedral shear stress in the model instead of the deviator stress.

$M_{r}=k_{1} \cdot p_{a} \cdot\left(\frac{\vartheta}{p_{a}}\right)^{k_{2}} \cdot\left(\frac{\tau_{\text {oct }}}{p_{a}}\right)^{k_{3}}$

where: $k_{1}, k_{2}$ and $k_{3}$ are regression analysis constants evaluated by the multiple regression analysis of experimental data. At the same time, the Austroroads theory [20] was considered.

Quality criteria and procedures for the investigation of stone grain mixtures, which are intended for unbound base and subbase, were provided by European standards [21-25].

\section{Loading conditions}

A simplified measure of traffic for pavement design ESAL (Equivalent Single Axle Load) was used. In the presented analyses, an ESAL is defined as a $100 \mathrm{kN}$ dual tire axle with a tire pressure of $690 \mathrm{kPa}$.

\subsection{Criteria}

\subsubsection{Single loading cycle}

An analysis that considers the following criteria must be satisfied during each cycle of load. The tensile strain of the asphalt layer $\varepsilon_{t, A}$ and the tensile strain of the geocell layers $\varepsilon_{t, C E L^{\prime}}$ both increased by the safety factor $S F$, should be less than their permissible strain $\varepsilon_{t, \text { lim }}[16,17]$.

$$
\begin{aligned}
& S F \cdot \varepsilon_{t, A} \leq \varepsilon_{t, A, l i m} \\
& S F \cdot \varepsilon_{t, C E L} \leq \varepsilon_{t, C E L, l i m}
\end{aligned}
$$

The stress-strain in the base and subbase layers (if they exist), and also in the subgrade, must be within the failure lines of the $p$ - $q$ stress space (Hornych et al [26]):

$$
S F \cdot \sigma_{d, B} \leq q_{f, B}
$$

where: $\sigma_{d, B}$ is the deviator stress in the base layer, SFis the safety factor and $q_{f, B}$ is the maximum stress, defined from material failure lines in the $p$ - $q$ stress space (based on laboratory tests). A similar relation is used for the sub-base layer and the subgrade

$$
\begin{aligned}
& S F \cdot \mathrm{s}_{d, S B} \leq q_{f, S B} \\
& S F \cdot \mathrm{s}_{d, S G} \leq q_{f, S G}
\end{aligned}
$$


The vertical strain of the base layer and both subbase and subgrade must be lower than the permissible value $\varepsilon_{v, l i m}$

$$
\begin{aligned}
& S F \cdot \varepsilon_{v, B} \leq \varepsilon_{v, B, l i m} \\
& S F \cdot \varepsilon_{v, S B} \leq \varepsilon_{v, S B, l i m} \\
& S F \cdot \varepsilon_{v, S G} \leq \varepsilon_{v, S G, l i m}
\end{aligned}
$$

\subsubsection{Repeated loading}

The expected life of the pavement is calculated by simulating traffic load strains, and by using an empirical transfer function to determine Allowed Repetitions for each load. If the applied load repetitions exceed the allowed repetitions, the pavement is assumed to have failed. Various correlations can be used to determine the maximum number of cyclic repetitions of traffic load. The correlation [27] is used to determine the tensile deformation of asphalt and the maximum number of cyclical repetitions of traffic loads $N_{p}$ according to equation (7):

$N_{F}=C_{F} \cdot K_{F 1} \cdot \varepsilon_{\mathbf{t}, \mathbf{A}}^{-K_{F 2}} \cdot E_{\mathbf{A}}^{-K_{F 3}}$

where: $E_{A}$ is the dynamic elasticity modulus of asphalt (psi), $\varepsilon_{t, A}$ is the lateral deformation of asphalt, $C_{F}$ is the correction factor and $K_{F 1^{\prime}} K_{F 2^{\prime}} K_{F 3}$ are constants.

The following Tseng and Lytton relationships [28] were used in the prediction of permanent strain in pavement structure:

$\varepsilon_{V, B, p}=\varepsilon_{v, B, \max } \cdot e^{-\left(\frac{\rho}{N}\right) \beta}$

where $\varepsilon_{v, B \text { max }}$ is the maximum permanent strain at a very high number of loading cycles, and $\rho$ and $\beta$ are the parameters. The parameters $\varepsilon_{V B \text { max }} \rho$ and $\beta$ were defined by laboratory tests using the repeated load triaxial apparatus and the Tseng and Lytton procedures [28].

Considering the thickness of base layer $h$, the permanent vertical deformation of the layer is:

$\delta_{V, B, p}=\frac{\varepsilon_{v, B, \max }}{\varepsilon_{v, B, r x}} \cdot e^{-\left(\frac{\rho}{N}\right) \beta} \cdot \varepsilon_{v, B} \cdot h$

where: $\varepsilon_{v, B, r x}$ is the resilient strain in the single loading cycle, computed from the FEM analysis.

By criterion of subgrade rutting [27], the maximum number of cyclical repetition of traffic loads $N_{R}$ is

$N_{R}=C_{R} \cdot K_{R 1} \cdot \varepsilon_{v, A}^{-K_{R}} \cdot E_{A}^{-K_{F 3}}$

where $C_{R}$ is the correction factor and $K_{R 1^{\prime}} K_{R 2}$ are constants.

\section{FEM analyses}

The analysis of stress and strain in pavement structure, based on the Finite Element Method (FEM), was conducted using the FEM program Everstress [29]. The purpose of the analysis was to examine the effect the reinforcement has on the pavement. Control calculations were implemented using the FEM program Plaxis [30]. Comparison of both results shows good correlation between displacements and stresses. Two distinct models were made:

- the basic model, without reinforcement

- the model in which the base layer is reinforced with geocells.

In the second model, the position of geocells in the base layer varied from bottom to top. The traffic axle load of $F=100$ $\mathrm{kN}$ and the wheel pressure of $p=690 \mathrm{kPa}$ was applied in the analysis. The analysis of the results focused on three criteria: tensile strain in asphalt, vertical strain in the base layer and vertical strain in the subgrade (Eq. 6, 9, 10).

\subsection{Unreinforced pavement structure}

The basic numerical model consisted of the asphalt layer, with thickness $d_{A^{i}}$ the base layer, with thickness $d_{B^{\prime}}$ and the subgrade, with a constant depth of $d_{S G}=150 \mathrm{~cm}$. The analysis was performed on variable thicknesses of asphalt layer $d_{A^{\prime}}$ and for the thickness of the base layer $d_{B^{\prime}}$ while the depth of the subgrade was constant and amounted to $d_{S G}=150 \mathrm{~cm}$. A variable value $\mathrm{E}_{\mathrm{SG}}$ was applied in the calculations, while the stiffness of asphalt $E_{A}$ and base layer $E_{B}$ was constant. The properties of layers were:

- Asphalt layer $\left(E_{A}=3 \mathrm{GPa}, v_{A}=0.40, d_{A}=10,20,30 \mathrm{~cm}\right)$

- Base layer $\left(k_{1}=200 \mathrm{MPa}, k_{2}=0.5, k_{3}=0, v_{B}=0.3, d_{B}=20\right.$, $40,60 \mathrm{~cm})$

- Subgrade layer $\left(E_{S G}=9 ; 14.7 ; 20.3 \mathrm{MPa}, v_{S G}=0.45, d_{S G}=150 \mathrm{~cm}\right)$.

Figure 6 shows the symmetric FEM model frame disposition. The results of the FEM analysis of the unreinforced pavement structure with properties of layers $d_{A^{\prime}} d_{B^{\prime}} E_{S G}$ are: tensile strain in the asphalt $\varepsilon_{t, A^{\prime}}$ vertical strain in the base layer $\mathrm{e}_{\mathrm{k}, B^{\prime}}$ vertical strain in the subgrade layer $\varepsilon_{\mathrm{v}, S G}$ number of repeating traffic loads $N_{F}$ and $N_{R^{\prime}}$

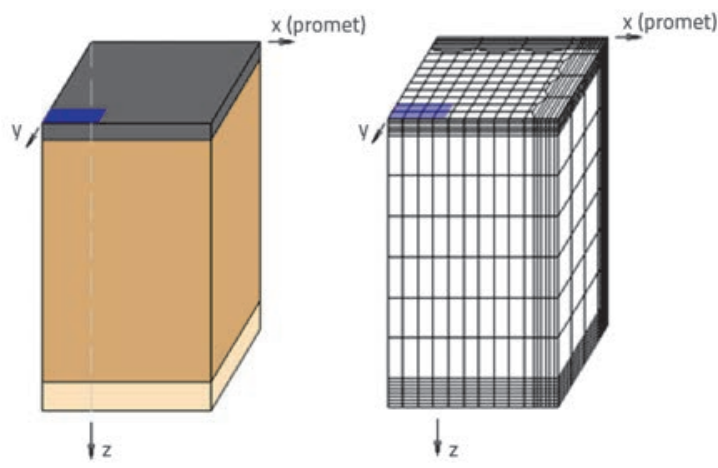

Figure 6. Numerical model without geocell 

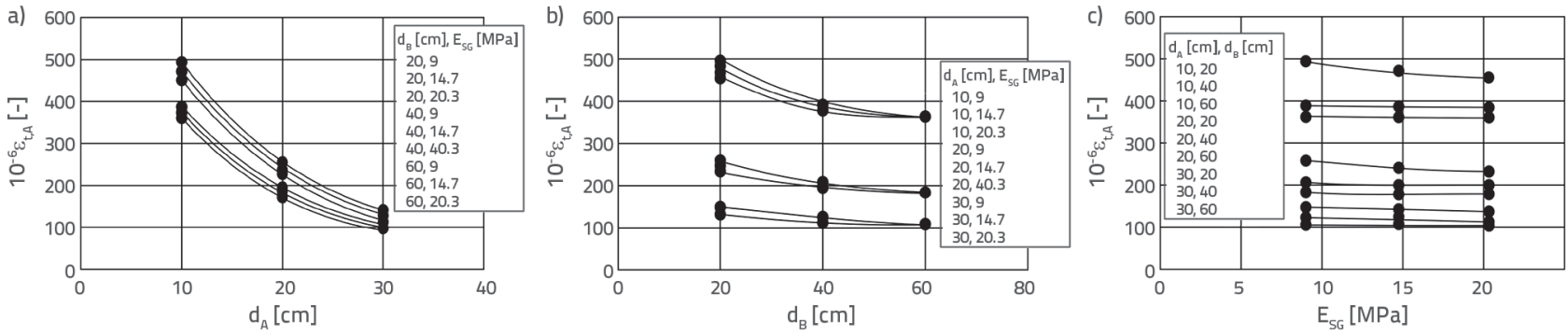

Figure 7. Tensile strain in asphalt $\varepsilon_{t A}$ vs: a) asphalt layer thickness $d_{B}$ at different values of base layer thickness $d_{B}$ and subgrade stiffness $E_{s d^{\prime}}$ b) base layer thickness $d_{B}$ at different values of asphalt layer thickness $d_{B}$ and subgrade stiffness $\left.E_{S G^{\prime}} \mathrm{c}\right)$ subgrade stiffness $E_{S G}$ at different values of asphalt layer thickness $d_{A}$ and base layer thickness $d_{B}$

\subsubsection{Tensile strain in asphalt}

The correlation between the tensile strain in asphalt $\varepsilon_{t A}$ and the asphalt layer thickness $d_{A}$ is shown in Figure 7.a for different values of base layer thickness $d_{B}$ and subgrade stiffness $E_{S G^{\prime}}$ The results show that the asphalt layer thickness $d_{A}$ has a high impact on the tensile strain in asphalt $\varepsilon_{t A^{*}}$. The correlation between the tensile strain in asphalt $e_{t A}$ and the thickness of base layer $d_{B^{\prime}}$ at different values of asphalt layer thickness $d_{A}$ and subgrade stiffness $E_{5 G^{\prime}}$ is shown in Figure 7.b. The results show that the thickness of base layer $d_{B}$ has a high impact on the tensile strain in asphalt $\varepsilon_{t A}$ only in case of large deformations (settlements) of pavement structure. The correlation between the tensile strain in asphalt $\varepsilon_{t, A}$ and subgrade stiffness $E_{S G^{\prime}}$ at various values of asphalt layer thickness $d_{A}$ and base layer thickness $d_{B^{\prime}}$ is shown in Figure 7.c. The results confirm that the stiffness of the subgrade $E_{5 G}$ has a low impact on tensile strain in asphalt layer $\varepsilon_{t, A}$ if the pavement structure is sufficiently dimensioned (low settlements).

Comparison of results for tensile strain in asphalt $\varepsilon_{t, A^{\prime}}$ between the unreinforced pavement structure and the geocell reinforced pavement beneath the asphalt, shows that a thin asphalt layer and an adequate stiffness of cells can have the same effect on tensile strain in asphalt $\varepsilon_{t A}$ as an increase in asphalt layer thickness.

\subsubsection{Vertical strain in base layer}

The correlation between the vertical strain in base layer $\varepsilon_{V, B}$ and asphalt layer thickness $d_{A^{\prime}}$ at various values of base layer thickness $d_{B}$ and subgrade stiffness $E_{S G}$ is shown in Figure 8.a. The results show that the thickness of asphalt layers $d_{A}$ has a high impact on vertical strain in base layer $\varepsilon_{v, B^{\circ}}$. The correlation between the vertical strain in base layer $e_{v, B}$ and the thickness of base layer $d_{B^{\prime}}$ at different values of asphalt layer thickness $d_{A}$ and subgrade stiffness $E_{S G^{\prime}}$ is shown in Figure 8.b. The results confirm that the thickness of base layer $d_{B}$ has a significant impact on vertical strain in base layer $\varepsilon_{v, B}$. The correlation between the vertical strain in base layer $\varepsilon_{v, B}$ and the stiffness of subgrade $E_{S G^{\prime}}$ at various values of asphalt layer thickness $d_{A}$ and base layer thickness $d_{B^{\prime}}$ is shown in Figure 8.c. The results show that the stiffness of subgrade $E_{S G}$ has a low impact on vertical strain in base layer $\varepsilon_{v, B}$ if pavement structure is sufficiently dimensioned (low settlements). The comparison of results for the vertical strain in base layer $\varepsilon_{v, B^{\prime}}$ between the unreinforced pavement structure and the geocell reinforced pavement beneath the asphalt, shows that a thin layer of asphalt and an adequate stiffness of geocells can reduce vertical strain in base layer $\varepsilon_{v, B}$ but cannot produce the same effect as when the asphalt layer thickness is increased.

\subsubsection{Vertical strain in subgrade layer}

The correlation between the vertical strain in subgrade layer $\varepsilon_{v, 56}$ and the thickness of asphalt layers $d_{A}$ at different values of base layer thickness $d_{B}$ and subgrade stiffness $E_{S G}$ is shown in Figure 9a. The results show that the thickness of the asphalt layers $d_{A}$ has a high impact on the vertical strain in subgrade layer $\varepsilon_{v, S G^{\circ}}$
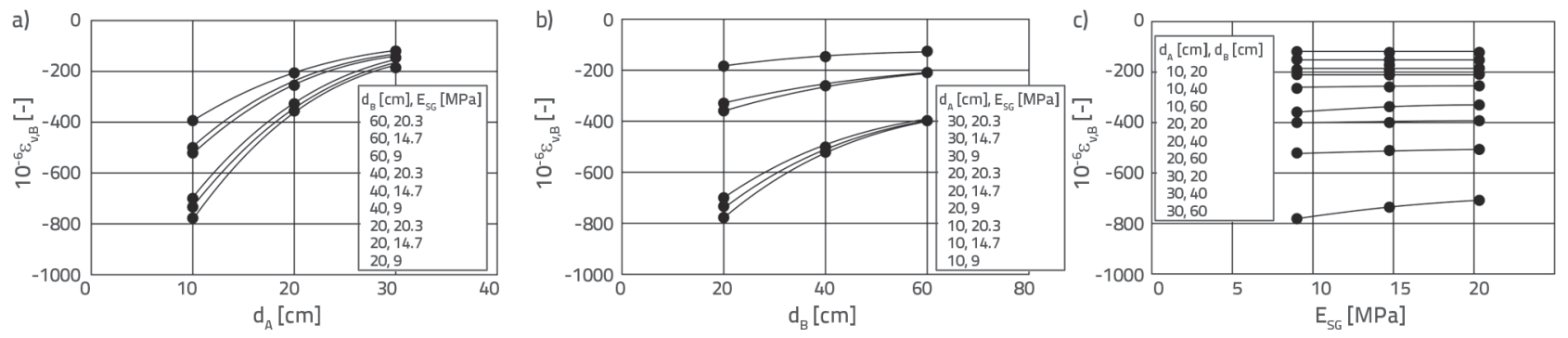

Figure 8. Vertical strain in base layer $\varepsilon_{v, B}$ vs: a) asphalt layer thickness $d_{A}$ at various values of base layer thickness $d_{B}$ and subgrade stiffness $E_{S G}$ i b) base layer thickness $d_{B}$ at various values of asphalt layer thickness $d_{A}$ and subgrade stiffness $\left.E_{S G^{\prime}} \mathrm{C}\right)$ subgrade stiffness $E_{S G}$ at various values of asphalt layer thickness $d_{A}$ and base layer thickness $d_{B}$ 

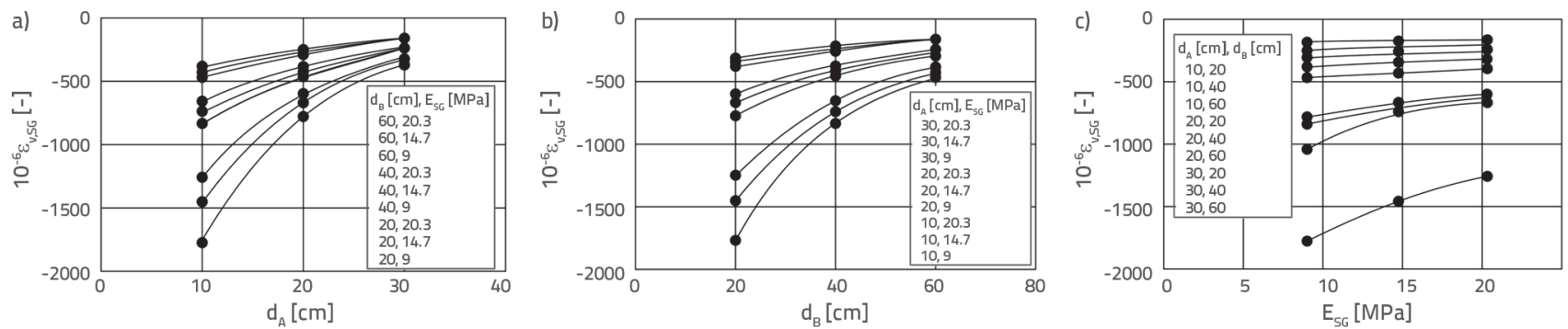

Figure 9. Vertical strain in subgrade layer $\varepsilon_{v, 5 G}$ VS: a) asphalt layer thickness $d_{A}$ at different values of base layer thickness $d_{B}$ and subgrade stiffness $E_{S G^{\prime}}$ b) base layer thickness $d_{B}$ at various values of asphalt layer thickness $d_{A}$ and subgrade stiffness $E_{S G^{\prime}}$ c) subgrade stiffness $E_{S G}$ at various values of asphalt layer thickness $d_{A}$ and base layer thickness $d_{B}$

The correlation between the vertical strain in subgrade layer $e_{v, S G}$ and the thickness of base layer $d_{B^{\prime}}$ at various values of asphalt layer thickness $d_{A}$ and subgrade stiffness $E_{S G}$ is shown in Figure 9.b. The results confirm that the thickness of base layer $d_{B}$ has a significant impact on the vertical strain in subgrade $\varepsilon_{v, B}$. The correlation between the vertical strain in subgrade $\varepsilon_{v, S G}$ and the stiffness of subgrade $E_{S G}$ at various values of asphalt layer thickness $d_{A}$ and base layer thickness $d_{B}$. is shown in Figure $9 \mathrm{c}$. The results show that the stiffness of subgrade $E_{S G}$ has an impact on vertical strain in subgrade $\varepsilon_{v, S G}$ if pavement structure is not sufficiently dimensioned.

\subsection{Reinforced pavement structure}

The numerical model of the reinforced pavement structure, with geocells in its base layer, consists of an asphalt layer with thickness $d_{A^{\prime}}$ an upper base layer with thickness $d_{B, U P^{\prime}}$ a layer of geocells with thickness $d_{C E L^{\prime}}$ a lower base layer with thickness $d_{B, \ell^{\prime}}$ and a subgrade with a constant depth of $d_{S G}=150 \mathrm{~cm}$. The analyses were performed with the constant thickness of the asphalt layer $d_{A}$ and base layer $d_{B^{\prime}}$ while the geocells thickness $d_{C E L}$ was a variable. The variable value $E_{S G}$ was applied to the calculations of subgrade. The stiffness value of geocells was also variable, while the stiffness values of asphalt $E_{A}$ and base layer $E_{B}$ were constant. Layer properties can be summarized as follows:

- Asphalt layer $\left(E_{A}=3 \mathrm{GPa}, v_{A}=0.40, d_{A}=10 \mathrm{~cm}\right)$

- Upper base layer $\left(k_{1}=200 \mathrm{MPa}, k_{2}=0.5, k_{3}=0, v_{B}=0.3, d_{B}=\right.$ 0 to $\left.40 \mathrm{~cm}-d_{C E L}\right)$
- Geocells $\left(E_{C E L}=200-3000 \mathrm{MPa}, v=0.20, d_{C E L}=5,10,15 \mathrm{~cm}\right)$

- Lower base layer $\left(k_{1}=200 \mathrm{MPa}, k_{2}=0.5, k_{3}=0, v_{B}=0.3, d_{B}=\right.$ 0 to $\left.40 \mathrm{~cm}-d_{C E L}\right)$

- Subgrade layer $\left(E_{S G}=9 ; 14.7 ; 20.3 \mathrm{MPa}, v_{S G}=0.45, d_{S G}=150 \mathrm{~cm}\right)$.

Generally, three models of reinforced pavement structures were analyzed: with geocells on top of the base layer, with geocells inside the base layer, and with geocells directly under the asphalt layer.

The results of the FEM analysis of the reinforced pavement structure with properties of layers $d_{A^{\prime}} d_{B^{\prime}} d_{C E L^{\prime}} E_{A^{\prime}} E_{C E L^{\prime}} E_{B^{\prime}} E_{S G^{\prime}}$ were expressed as: tensile strain in asphalt $\varepsilon_{t, A^{\prime}}$ tensile strain in geocells $\varepsilon_{C E L^{\prime}}$ vertical strain in base layer $\varepsilon_{v, B^{\prime}}$ vertical strain in subgrade layer $\varepsilon_{\mathrm{v}, S G^{\prime}}$ number of repeating traffic loads $N_{F}$ and $N_{\dot{r}}$

\subsubsection{Tensile strain in asphalt}

Figure 10.a shows the correlation between the tensile strain in asphalt $\varepsilon_{t A}$ and the stiffness of geocells $E_{S G}$, with a geocell thicnkness of $d_{C E L}=10 \mathrm{~cm}$ and a subgrade stiffness of $E_{S G}=$ 20.3 MPa, for the geocells directly under the asphalt layer. The results show that the geocell stiffness $E_{S G}$ has a high impact on the tensile strain in asphalt $\varepsilon_{t, A}$. The geocells thickness $d_{C E L}$ also has a significant impact on the tensile strain in asphalt $e_{t, A^{*}}$ Figure 10.b shows the correlation between the tensile strain in asphalt $\varepsilon_{t, A}$ and the geocell stiffness $E_{C E L}$ at various values of geocell thickness $d_{C E L}$ and subgrade stiffness $E_{S G}$ - geocells are in contact with subgrade. The results show that geocells do not exert a significant impact on the tensile strain in asphalt $\varepsilon_{t, A^{*}}$
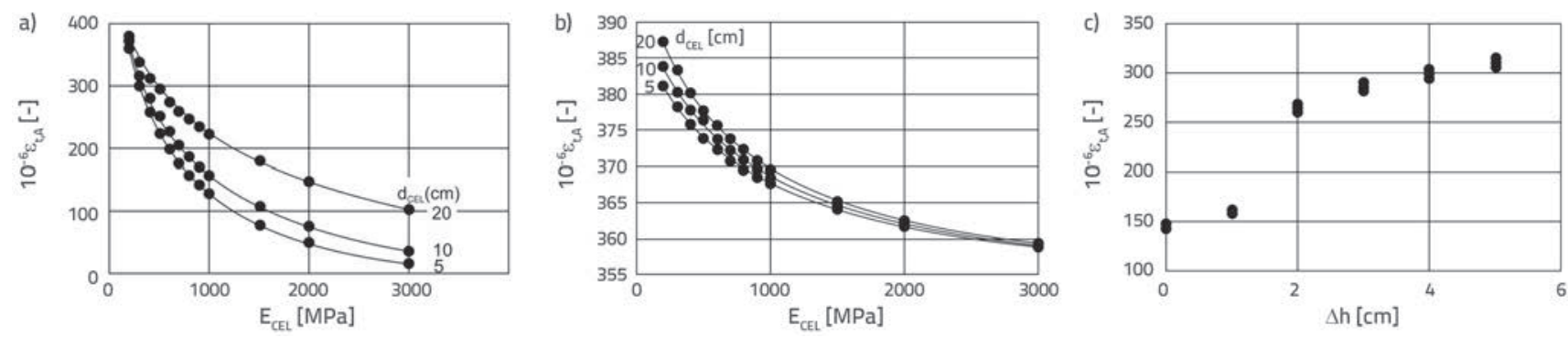

Figure 10. Typical tensile strain in asphalt $\varepsilon_{t, A}$ vs: a)geocells stiffness $E_{S d^{\prime}}$ for geocells directly under asphalt layer; b) geocell stiffness $E_{C E L}$ at various geocell thicknesses $d_{C E^{\prime}}$ geocells are in contact with subgrade; c) distance between geocells and asphalt $\Delta h$ 
The distance of geocells from asphalt $\Delta h$ was analysed. Figure $10 \mathrm{c}$ shows the correlation between the tensile strain in asphalt $\varepsilon_{t, A}$ and the distance of geocells from asphalt for specific geocell characteristics $\left(\mathrm{E}_{\mathrm{CEL}}=2000 \mathrm{MPa}, \mathrm{d}_{\mathrm{CEL}}=5 \mathrm{~cm}\right)$ and ground conditions $\left(E_{S G}=9-20.3 \mathrm{MPa}\right)$. The results show that the tensile strain in asphalt $\varepsilon_{t, A}$ is the lowest when geocells are in contact or at very slight distance from the asphalt. There is a significant increase of tensile strain in asphalt when the distance between geocells and asphalt exceeds $1 \mathrm{~cm}$. When the distance is beyond $2 \mathrm{~cm}$, the tensile strain in asphalt increases constantly with an increase in distance, but at lower rate.

Based on this analysis, it can be concluded that the placement of geocells has a significant impact on the transverse tension in asphalt, and that the location of geocells just below asphalt is advantageous and contributes significantly to the reduction of deformation. The significance of using geocells decreases rapidly with an increase in installation depth.

\subsubsection{Vertical strain in base layer}

Figure 11.a shows the correlation between the vertical strain in base layer $\varepsilon_{v, B}$ and geocell stiffness $E_{C E L^{\prime}}$ the geocells being directly under the asphalt layer, at different values for geocell thickness $d_{C E L}$ and subgrade stiffness $E_{S G}$. The results show that geocell stiffness $E_{C E L}$ and geocell thickness $d_{C E L}$ have a high

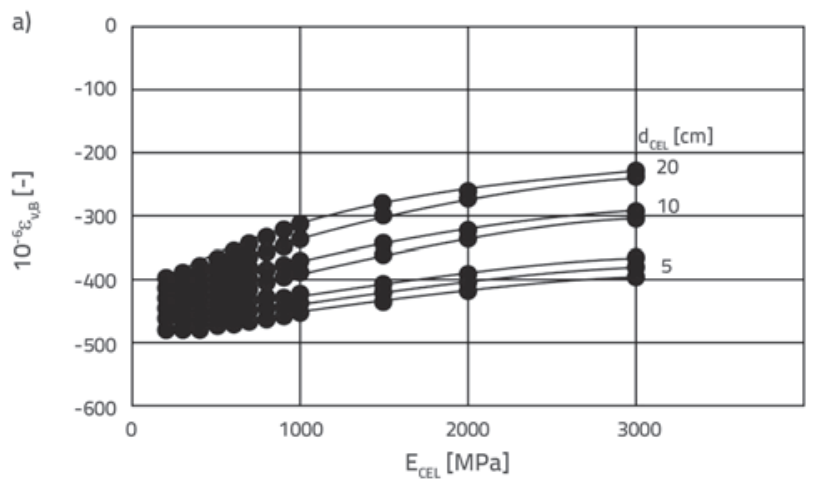

impact on the vertical strain in base layer $\varepsilon_{v, B^{\prime}}$. Figure 11.b shows the correlation between the vertical strain in base layer $\varepsilon_{v, B}$ and geocell stiffness $E_{C E L}$ (geocells are in contact with subgrade), at different geocell thicknesses $d_{C E L}$. The results show that geocell stiffness $E_{C E L}$ has a high impact on the vertical strain in base layer $\varepsilon_{v, B^{\prime}}$ while geocell thickness $d_{C E L}$ has no significant impact on the vertical strain in base layer $\varepsilon_{v, B^{\prime}}$. Results for geocells inside the base layer range between extreme values shown in Figure 11.a and Figure 11.b and depend on the distance between geocells and asphalt.

\subsubsection{Vertical strain in subgrade}

Figure 12.a shows the correlation between the vertical strain in subgrade layer $\varepsilon_{v, S G}$ and the stiffness of geocells $E_{C E L^{\prime}}$ for the geocells directly under the asphalt layer, at different geocell thicknesses $d_{C E L}$ and subgrade stiffness $E_{S G}$ The results show that the stiffness of the geocells $E_{C E L}$ has no important influence on the vertical strain in subgrade layer $\varepsilon_{v, S G}$ However, the thickness of geocells $d_{C E L}$ has a significant impact on the vertical strain in subgrade layer $\varepsilon_{v, S G}$. Figure 12 .b shows the correlation between the vertical strain in subgrade layer $\varepsilon_{v S G}$ and geocell stiffness $E_{C E L^{\prime}}$ for geocells in contact with subgrade, at various values of geocell thickness $d_{C E L^{L}}$. The results show that the stiffness of geocells $E_{C E L}$ has an influence on the vertical strain in

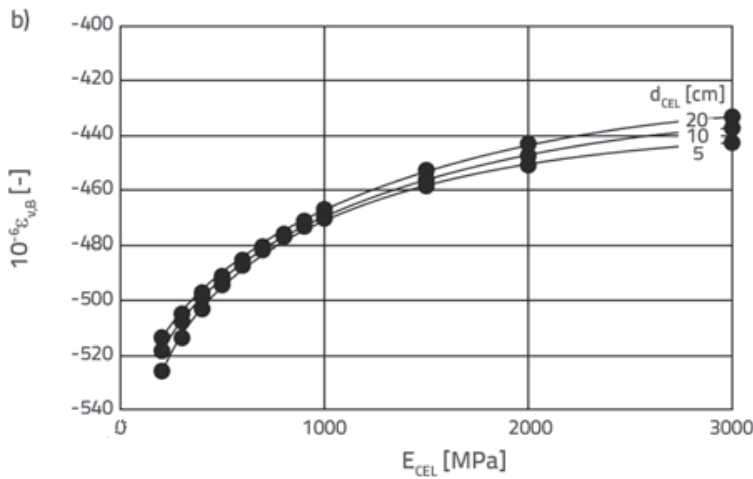

Figure 11. Vertical strain in base layer $\varepsilon_{V, B}$ VS. geocell stiffness $E_{C E L}$ at various geocell thicknesses $d_{C E L}$ a) the geocells are positioned directly under the asphalt layer; b) the geocells are in contact with subgrade
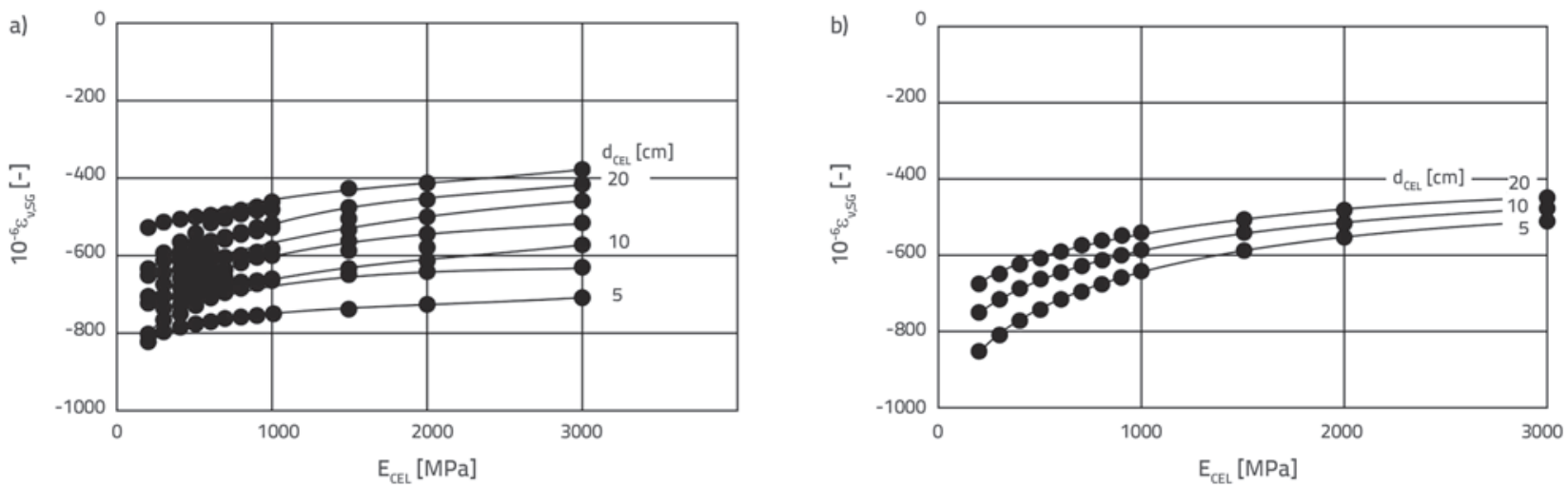

Figure 12. Vertical strain in subgrade layer $\varepsilon_{v, S G}$ vs. geocell stiffness $E_{C E L}$ at various geocell thicknesses $d_{C E L}:$ a) for geocells directly under the asphalt layer; b) for geocells in contact with the subgrade 

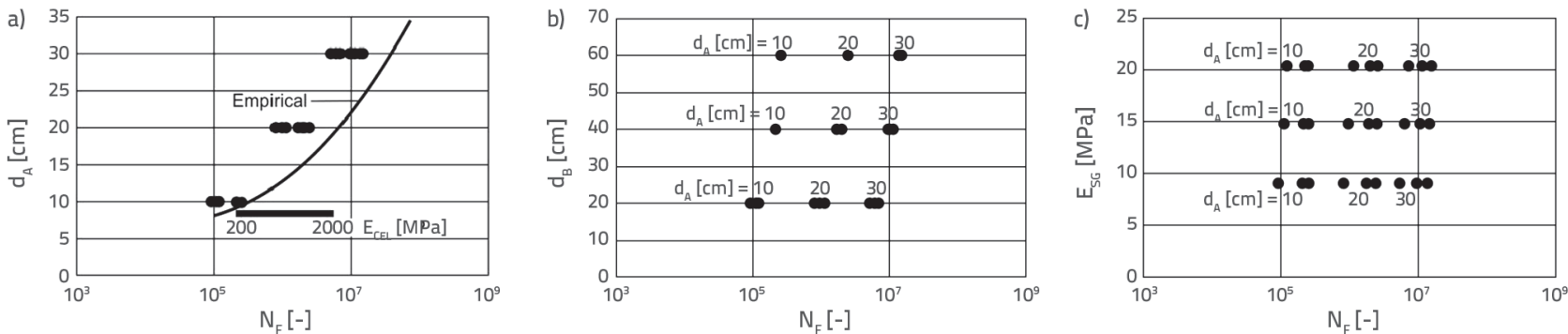

Figure 13. a) Number of repeated loadings $\boldsymbol{N}_{F}$ in life cycle vs. asphalt layer thickness $\boldsymbol{d}_{A}$ for unreinforced pavement (FEM and empirical), compared to the increasing number of repeating loadings $N_{F}$ in life cycle for asphalt layer with constant thickness and an increasing stiffness of geocells; b) Number of repeated loadings $N_{F}$ in life cycle vs. base layer thickness $d_{B^{\prime}}$ c) Number of repeated loadings $N_{F}$ in life cycle vs. subgrade stiffness $E_{S G}$

subgrade layer $\varepsilon_{v, S G}$ Results for geocells inside the base layer are between the extreme values shown in Figure 12.a and Figure 12.b, which is dependent on the distance between geocells and asphalt. The results show that vertical strain in subgrade layer $\varepsilon_{v, S G}$ is smaller when geocells are deeper in base layer.

\subsection{The effect of reinforcement}

Tensile strain in asphalt $\varepsilon_{t, A}$ is highly important for the life cycle of pavement structures. Figure 13.a shows the correlation between the maximum number of repeated loadings $N_{F}$ and asphalt layer thickness $\varepsilon_{t, A}$ (Eq. 7). For unreinforced pavement,
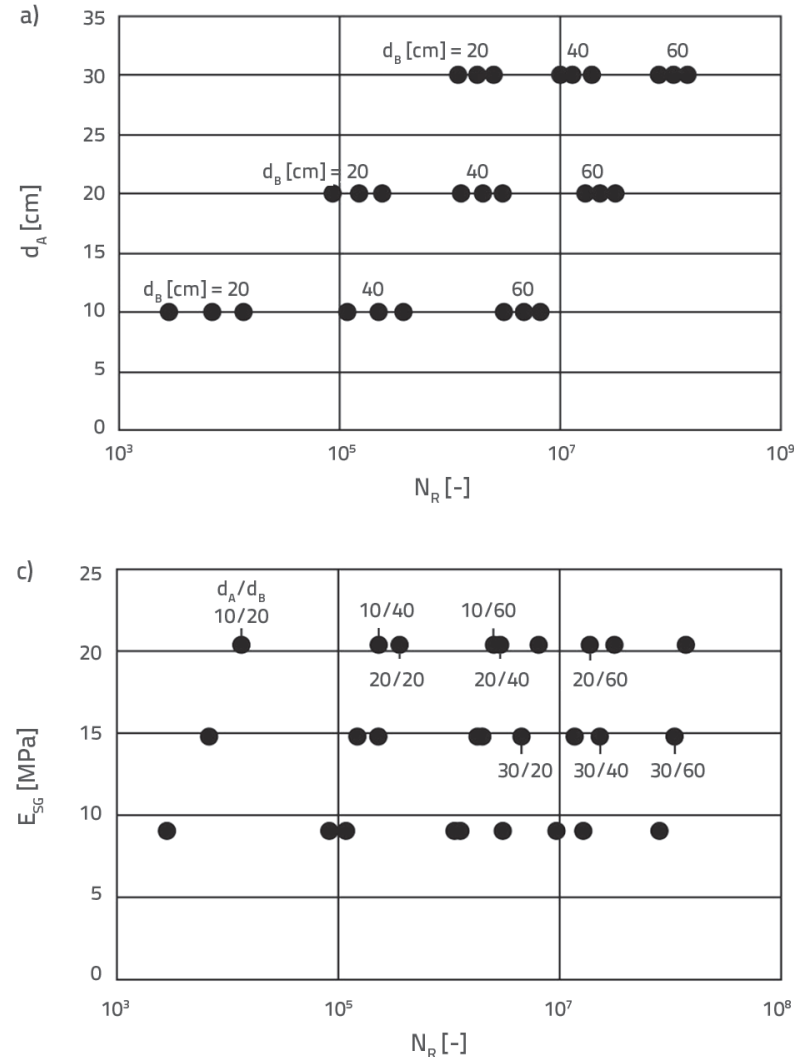

the results of FEM Analysis are similar to the results of the empirical method [31], which did not take into account the conditions of the subgrade; the number of passes depended only on the dimensions of the asphalt. The number of repeated loads significantly increases when the pavement is reinforced on top of the base layer with geocells only $5 \mathrm{~cm}$ in thickness (depending on the stiffness of the geocells). Similarly, the correlation between the maximum number of repeated loadings $N_{F}$ and base layer thickness $d_{B}$ (Figure 13.b) is presented, as well as the correlation between the maximum number of repeated loadings $N_{F}$ and subgrade stiffness $E_{S G}$ (Figure 13.c). The vertical strain in subgrade layer $\varepsilon_{v, S G}$ is highly important

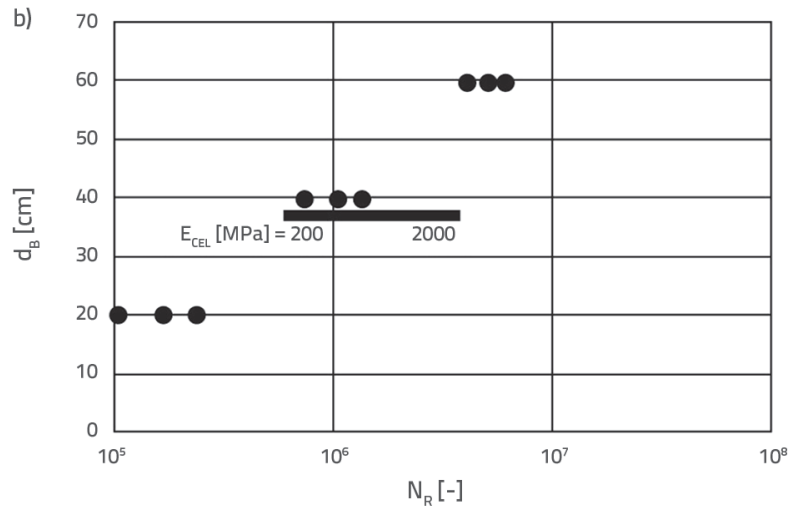

Figure 14. a) Number of repeated loadings $N_{P}$ in life cycle vs asphalt layer thickness $d_{A} ;$ b) $d_{B}\left(d_{A}=10 \mathrm{~cm}\right)$ compared to an increasing number of repeating loadings $N_{R}$ in life cycle for constant asphalt layer thickness and an increasing stiffness of geocells; c) Number of repeated loadings $N_{R}$ vs. subgrade stiffness $\mathrm{E}_{\mathrm{SG}}$ 

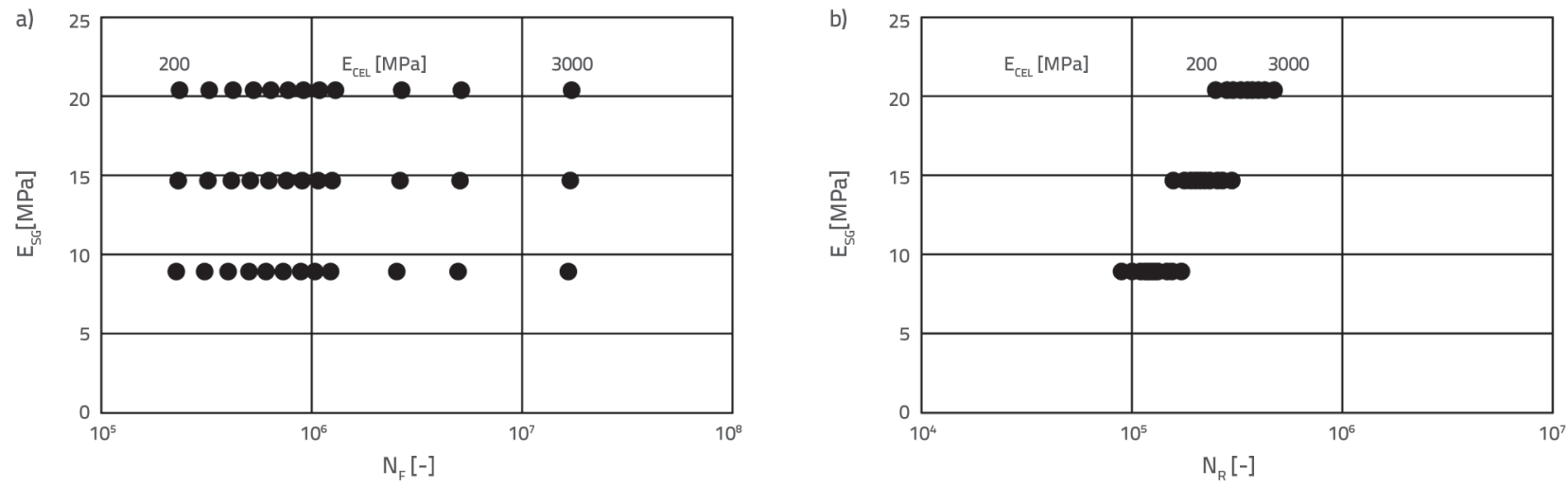

Figure 15. a) Number of repeated loadings NF in life cycle vs. subgrade stiffness $E_{S G}$ (geocells placed directly under asphalt); b) Number of repeated loadings NR in life cycle vs. subgrade stiffness $E_{s G}$ (geocells placed directly under asphalt)
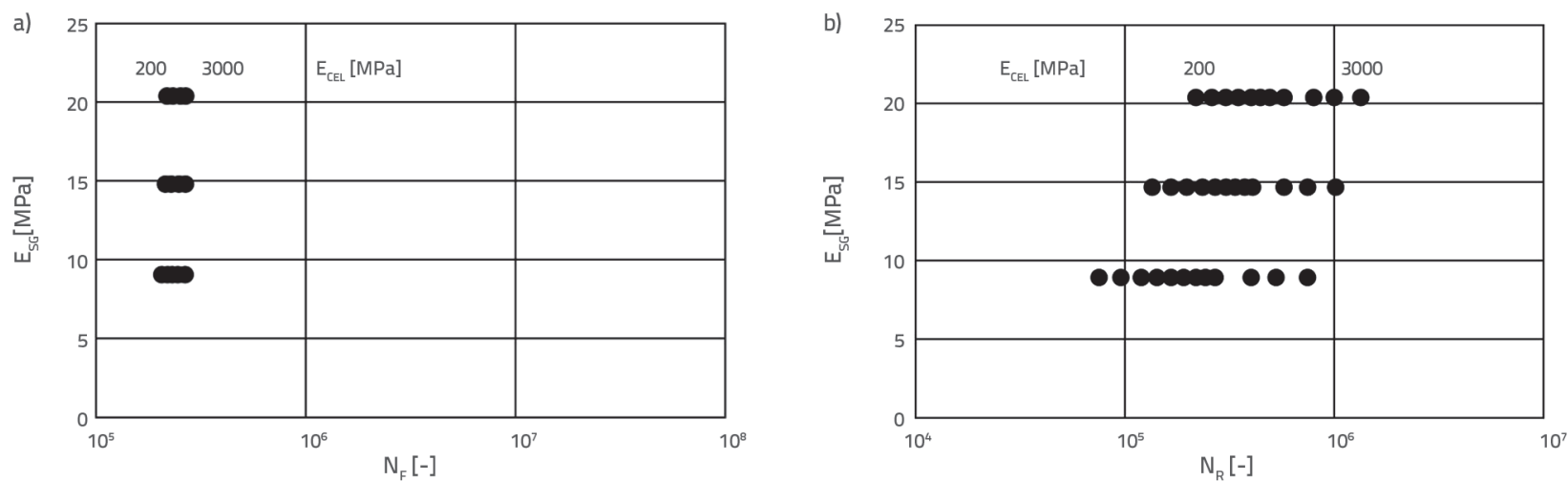

Figure 16. a) Number of repeated loadings $N_{R}$ in life cycle vs. subgrade stiffness $E_{5 G}$ geocells in contact with subgrade; b) geocells in contact with subgrade

for the life cycle of pavement structures. Figure 14.a shows the correlation between the maximum number of repeated loadings $N_{R}$ and asphalt layer thickness $d_{A}$ (eq. 10) for different thicknesses of base layer $d_{B}$ and different subgrade stiffness values $E_{S G}$ Similarly, the correlation between the maximum number of repeated loadings $N_{R}$ and base layer thickness $d_{B}$ (Figure 14.b) is presented, as well as the correlation between the maximum number of repeated loadings $N_{R}$ and subgrade stiffness $E_{S G}$ (Figure 14.d). Figure 14.c shows the correlation between the maximum number of repeated loadings $N_{R}$ and base layer thickness $d_{B}$ (eq. 10) for an unreinforced pavement and pavement that has been reinforced at the bottom of the base layer with geocells $5 \mathrm{~cm}$ in thickness.

The results show that the geocells installed directly under the asphalt have a high impact on the number of repeated loadings $N_{F}$ in life cycle (tensile strain of asphalt layer), see Figure 15.a, and a low impact on the number of repeated loadings $N_{R}$ in life cycle (vertical strain of subgrade), see Figure 15.b.

The situation is quite the opposite for geocells in contact with subgrade: they have a low impact on the number of repeated loadings $N_{F}$ in life cycle (tensile strain of asphalt layer), see Figure 16.a, and a high impact on the number of repeated loadings $N_{R}$ in life cycle (vertical strain of subgrade), see Figure 16.b.

\section{Conclusion}

Both an investigation and a parametric study were conducted to analyse an innovative approach to the design of geocellreinforced flexible pavements. Extensive research conducted to this effect involved: analytical solutions, numerical analyses, a parametric study, experimental analyses, experimental laboratory tests, and field experiments. The parametric study is presented in the paper. The results are consistent with other above-mentioned analyses.

The parametric study was conducted based on the results obtained by FEM analysis. The FEM analysis included unreinforced and geocell-reinforced pavements with various positions of geocells and various stiffness and thickness values of geocells. The following findings were obtained in the scope of the parametric study:

- Geocells significantly increase the capacity of the asphalt layers of pavement structures, and reduce permanent deformation in asphalt. Therefore, the use of geocells could significantly reduce the asphalt-layer thickness and/or increase life time of pavement structures.

- The results show that the stress - strain state in pavement layers mostly depends on the location of geocells in the base layer and the stiffness of geocells. When geocells 
are positioned directly under the asphalt, the stiffness of geocells has a high impact on the tensile strain of asphalt.

- The stiffness and thickness of geocells also have a high impact on vertical strain in base layer, while they have no important influence on vertical strain in subgrade layer.

- The thickness of geocells also has a significant impact on the tensile strain of asphalt.

- When geocells are positioned on top of the subgrade, the stiffness and thickness of the geocells have an impact on vertical strain in base layer and on vertical strain in subgrade. They have no significant impact on tensile strain in asphalt. This effect is reduced significantly when the distance between geocells and asphalt exceeds $1 \mathrm{~cm}$.

\section{REFERENCES}

[1] Road Statistics Yearbook, European Union Road Federation, http://www.erf.be/images/Statistics/ ADprint-ERFSTATS2016. pdf, 2016

[2] Cowland, J., Wong, S.: Performance of a Road Embankment on Soft Clay Supported on a Geocell Mattress Foundation, Geotextiles and Geomembranes, pp. 687-705, 1993, https://doi. org/10.1016/0266-1144(93)90046-Q

[3] Dash, S.K., Sireesh, S., Sitharam, T.: Model studies on circular footing supported on geocell reinforced sand underlain by soft clay, Geotextiles and Geomembranes, pp. 197-219, 2003, https:// doi.org/10.1016/S0266-1144(03)00017-7

[4] Dash, S., Rajagopal, K., Krishnaswamy, K.: Behaviour of geocell reinforced sand beds under strip loading. Canadian Geotechnical Journal, 44 (2007), pp. 905-916, https://doi.org/10.1139/t07-035

[5] Yang, X., Han, J., Pokharel, SK, Manandhar, C., Parsons, RL., Leshchinsky, D.: Accelerated pavement testing of unpaved roads with geocellreinforced sand bases, Geotextiles and Geomembranes, 32 (2012), pp. 95-103.

[6] Bathurst, R., Karpurapu, R.: Large scale triaxial compression testing of geocell reinforced granular soils. Geotechnical Testing Journal, 16 (1993) 3., pp. 296-303.

[7] Rajagopal, K., Krishnaswamy, N.R., Madhavi Latha, G.: Behavior of sand confined in single and multiple geocells. Geotextiles and Geomembranes, 3 (1999) 154, pp. 171-184.

[8] Mengelt, M., Edil, T., Benson, C.: Resilient modulus and plastic deformation of soil confined in a geocell. Geosynthetics International, 5 (2006).

[9] Wasseloo, J., Visser, A., Rust, E.: The stress-strain behaviour of multiple cell geocell packs. Geotextiles and Geomembranes, 27 (2009), pp. 31-38, https://doi.org/10.1016/j. geotexmem.2008.05.009

[10] Pokharel, S.K., Letchkinsky, D., Parsons, R.L., Halahmi, I.: Investigation of factors influencing behaviour of single geocell-reinforced bases under static loading, Geotextiles and Geomembranes, 28 (2010), pp. 570-578, https://doi. org/10.1016/j.geotexmem.2010.06.002

[11] Al-Qadi, I., Hughes, J.: Geocell subgrade stabilization, Washington DC: US Department of Transportation, 1999.
- The geocells installed at the bottom of base layer improve the capacity of subgrade and reduce the permanent vertical deformation of base layer. Geocells affect the reduction of shear deformation in the base layer directly at the position of the reinforcement.

The conclusion of the parametric study is: geocells have an effect on tensile strain of asphalt only when they are placed in contact with asphalt, or just beneath the asphalt. When they are placed lower in the base layer, the effect on asphalt reduces significantly. Geocells installed deeper or at the bottom of the base layer improve the capacity of subgrade and reduce the permanent vertical deformation of the base layer.

[12] Latha, G.M., Dash, S., Rajagopal, K.: Numerical simulation of the behavior of geocell reinforced sand in foundations. International Journal of Geomechanics ASCE, 9 (2009) 4, pp. 143-152, https:// doi.org/10.1061/(ASCE)1532-3641(2009)9:4(143)

[13] Lenart, S., Medved, S.P., Zlender, B.: Laboratory testing of pavement structure by traffic load simulation, Proceedings of the $19^{\text {th }}$ ICSMGE, 2017, Seoul

[14] Medved, S.P., Žlender, B., Lenart, S., Jelušič, P.: Modeling of geocellreinforced pavement - experimental validation, Acta Geotechnica Slovenica, 2 (2016), pp. 3-14.

[15] Medved, S.P., Žlender, B., Lenart, S.: Geocell reinforced pavement, $1^{\text {st }}$ International Conference on Construction Materials for Sustainable Future - CoMS 2017, Zadar, 2017.

[16] Zhou, H., Wen, X.: Model studies on geogrid- or geocell-reinforced sand cushion on soft soil. Geotextiles and Geomembranes, 26 (2008), pp. 231-238, https://doi.org/10.1016/j. geotexmem.2007.10.002

[17] Ling, Z., Zhao, M., Shi, C., Zhao, H.: Bearing capacity of geocell reinforcement in embankment engineering. Geotextiles and Geomembranes, 28 (2010), pp. 475-482, https://doi. org/10.1016/j.geotexmem.2009.12.011

[18] Avesani, N., Bueno, B., Futai, M.: A bearing capacity calculation method for soil reinforced with a geocell. Geosynthetics International, 3 (2013).

[19] Witczak, M., Uzan, J.: The Universal Airport Pavement Design System: Granular Material Characterization. University of Maryland, Department of Civil Engineering, Maryland, 1988

[20] Austroroads Ltd, Development of a Nonlinear Finite Element Pavement Response to Load Model, 2012.

[21] European Standard EN 1744:2003 Tests for mechanical and physical properties of aggregates

[22] European Standard EN 993:2003 Tests for geometrical properties of aggregates

[23] European Standard EN 1097:2003 Tests for mechanical and physical properties of aggregates

[24] European Standard EN 12697-24: 2004 
[25] European Standard, SIST EN 13286-7:2004 Unbound and hydraulically bound mixtures - Part 7. Repeated load triaxial test for unbound mixtures.

[26] Hornych, P., Corte, J., Paute, J.: Etude des déformations permanentes sous chargements répétés de trois graves non traitées, Bulletin de liaison des Laboratoires des Ponts et Chaussées, 184 (1993), pp. 45-55.

[27] Finn, F.N., Saraf, C.L., Kulkrani, R., Nair, K., Smith, W., Abdulah, A.: Development of Pavement Structural Subsystems, National Cooperative Highway Research Program (NCHRP) Report 291، Washington, DC, 1986
[28] Tseng, K., Layton, R.: Prediction of Permanent Deformation in Flexible Pavements Materials in Implication of Aggregates in the Design, Construction, and Performance of Flexible Pavements, American Society for Testing and Materials, 1989

[29] Everstress Pavement Analysis Programs, Washington State Department of Transportation, s.l.: Oylimpia, WA., 1999

[30] PLAXIS B.V, Reference Manual for Plaxis 2D version 8.0. Delft: s.n., 2006

[31] TSC 06.520: 2008 Projektiranje, Dimenzioniranje novih asfaltnih voziščnih konstrukcij, Ur. I. RS, št. 65/09, DRSC, 2009. 